LBL-36122

UC- $=0$

950

\title{
Comparison of Financing Costs for Wind Turbine and Fossil Powerplants
}

\author{
Edward Kahn
}

\author{
Energy \& Environment Division \\ Lawrence Berkeley Laboratory \\ University of California \\ Berkeley, California 94720
}

February 1995

The work described in this study was funded by the Analysis and Systems Division, Office of Coal, Nuclear, Electric and Alternative Fuels, Energy Information Administration of the U.S. Department of Energy under Contract No. DE-AC0376 SF00098. 


\section{DISCLAIMER}

This report was prepared as an account of work sponsored by an agency of the United States Government. Neither the United States Government nor any agency thereof, nor any of their employees, make any warranty, express or implied, or assumes any legal liability or responsibility for the accuracy, completeness, or usefulness of any information, apparatus, product, or process disclosed, or represents that its use would not infringe privately owned rights. Reference herein to any specific commercial product, process, or service by trade name, trademark, manufacturer, or otherwise does not necessarily constitute or imply its endorsement, recommendation, or favoring by the United States Government or any agency thereof. The views and opinions of authors expressed herein do not necessarily state or reflect those of the United States Government or any agency thereof. 


\section{DISCLAIMER}

Portions of this document may be illegible in electronic image products. Images are produced from the best available original document. 


\section{Contents}

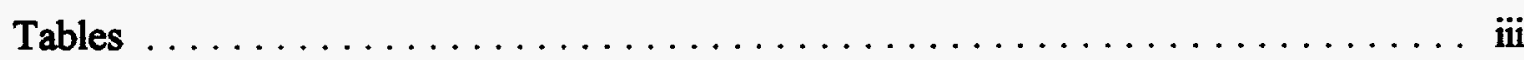

Acknowledgments $\ldots \ldots \ldots \ldots \ldots \ldots \ldots \ldots \ldots \ldots \ldots \ldots \ldots \ldots \ldots, \ldots \ldots \ldots$

Executive Summary $\ldots \ldots \ldots \ldots \ldots \ldots \ldots \ldots \ldots \ldots \ldots \ldots \ldots \ldots \ldots \ldots$ vii

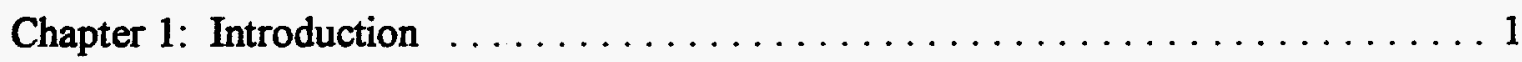

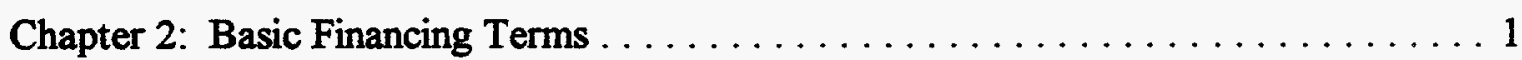

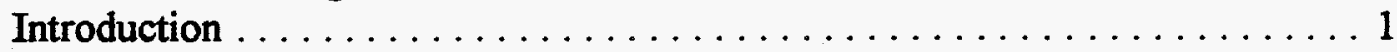

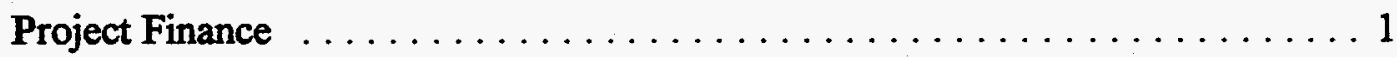

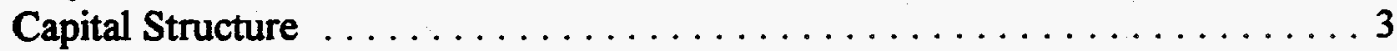

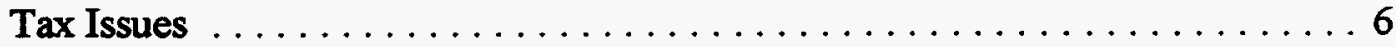

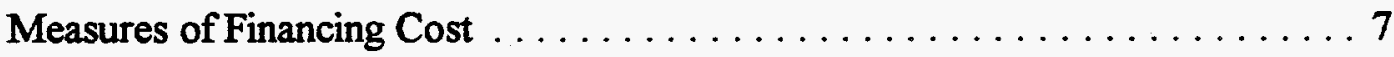

Chapter 3: Empirical Measures of Financing Terms $\ldots \ldots \ldots \ldots \ldots \ldots \ldots \ldots$

Data Availability and Method of Approach $\ldots \ldots \ldots \ldots \ldots \ldots \ldots \ldots$

Recent Transactions .....................

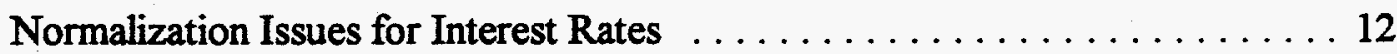

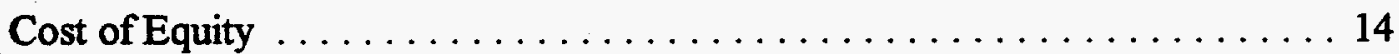

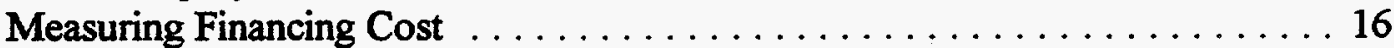

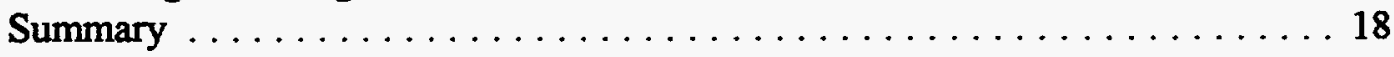

Chapter 4: Economic Analysis of Empirical Results $\ldots \ldots \ldots \ldots \ldots \ldots \ldots \ldots$

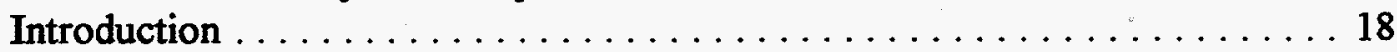

The Production Credit is a Financial Constraint $\ldots \ldots \ldots \ldots \ldots \ldots \ldots 18$

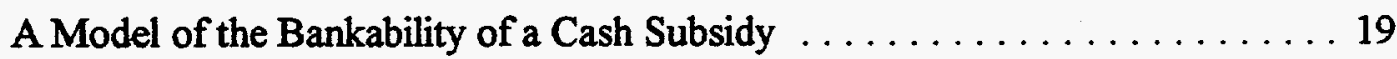

Estimating the Magnitude of a Bankable Production Credit $\ldots \ldots \ldots \ldots 21$

Budgetary Implications $\ldots \ldots \ldots \ldots \ldots \ldots \ldots \ldots \ldots \ldots \ldots \ldots \ldots \ldots \ldots \ldots, 22$

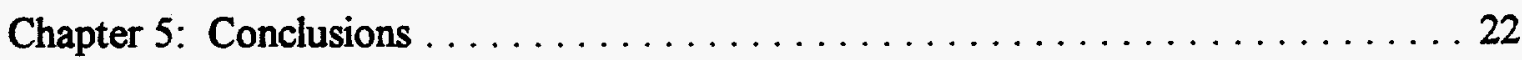

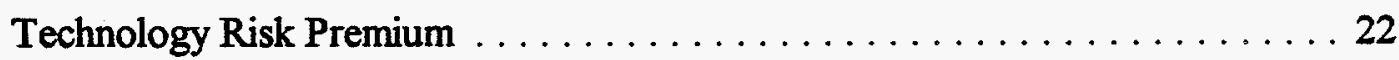

Resource Variability Risk . . . . . . . . . . . . . . . . . . 23

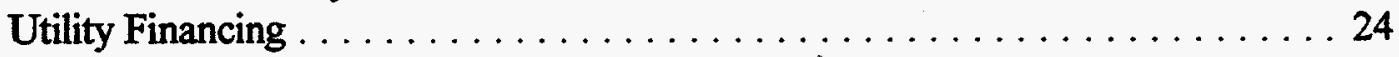

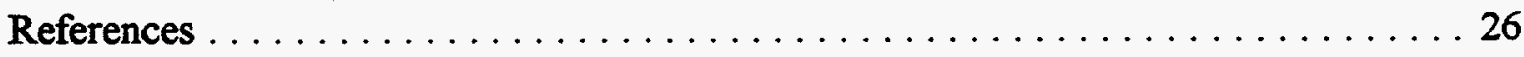




\section{Tables}

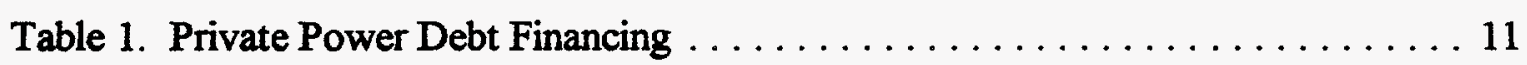

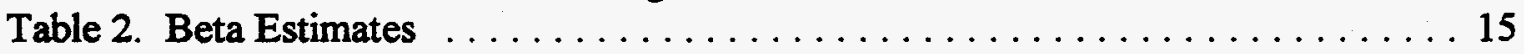

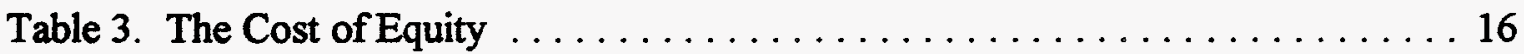

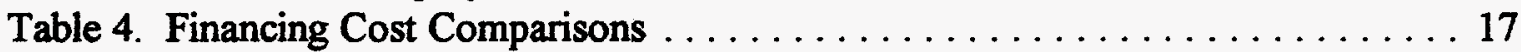

Table 5. Financing Effect of a Cash Production Credit $\ldots \ldots \ldots \ldots \ldots \ldots \ldots \ldots$ 


\section{Acknowledgments}

Information, assistance and review comments were provided by ...

Kevin Butler

FlowWind Corporation

Brian Caffyn

Cannon Power Corporation

Stan Hadley

Oak Ridge National

Laboratory
Dan Kirshner

Environmental Defense Fund

Meg Meal

Morse, Richard, Weisenmiller

and Associates

David Perlman

Salomon Brothers
Irv Rotter

Sidley and Austin

Don Wong

Kenetech

Tim Belden, LBL, provided research assistance. None of these individuals are responsible for any errors or opinions expressed here. This work was supported by the Analysis and Systems Division, Office of Coal, Nuclear, Electric and Alternative Fuels, Energy Information Administration of the U.S. Department of Energy under Contract No. DE-AC03-76SF00098. 


\section{Executive Summary}

This report compares the financing costs of wind turbine and conventional fossil powerplants. In both cases, the basic financial structure is assumed to be based on private power developers using a project finance arrangement. This is the dominant method used for wind turbine projects and is very widely used for conventional fossil powerplants.

We measure financing cost using the weighted average cost of capital. The two principal forms of finance are common equity and long term debt. The capital structure of a project reflects the weights of each type of capital.

In the past two years there have been only two wind turbine projects that have been financed, so the basis for broad conclusions is limited. Nonetheless, there appears to be a significant advantage in financing costs for conventional projects compared to wind turbines. There are two sources for the disadvantage facing wind projects. First, the cost of equity capital is significantly more expensive for wind than for conventional powerplants. Secondly, the capital structure of wind projects has a much greater fraction of this expensive equity than conventional alternatives.

The expensive common equity for wind turbine projects appears to reflect the perception of technological risk. The capital structure effect, however, may be an unintended effect of the production tax credit created in the Energy Policy Act of 1992. The tax credit is a benefit to equity investors only. It does not help projects sustain debt by creating cash that can be used to repay lenders. We estimate that if the production credit were paid in cash as opposed to a tax credit, much of the capital structure disadvantage for wind turbine projects would be eliminated. 


\section{Introduction}

This paper compares the financing costs of wind turbine powerplants with those of fossil powerplants. The goal of this examination is to determine the extent to which these costs differ and what the sources of such differences may be.

The discussion is organized in the following fashion. Section 2 introduces basic terminology and concepts from finance, as they apply in the powerplant setting. Section 3 reviews available data from a variety of sources to estimate the magnitude of the variables identified in Section 2. In Section 4 we examine the effect of the production tax credit enacted in the Energy Policy Act of 1992 on the financing of wind turbine projects. Conclusions are offered in Section 5 .

\section{$2 \cdot$ Basic Financing Terms}

\subsection{Introduction}

In this section, we define the basic terms associated with financing powerplants. In Section 2.2 we discuss project finance. This is the dominant mechanism for financing private power projects. Since wind turbine power plants and their chief competitors, combined cycle power plants, are primarily developed by independent power producers, we will focus attention on the project finance mechanism. Concepts associated with capital structure are defined in Section 2.3. Section 2.4 addresses tax issues. Finally, Section 2.5 defines basic measures of financing cost.

\subsection{Project Finance}

Project and corporate finance differ primarily in how borrowing is done in the two mechanisms. When corporations borrow money in either the public or private markets, the support for their credit is based on income streams coming from many assets. The vast majority of corporations sell more than one product, so the total income stream is diversified over the sales of each product. By contrast, project finance is built around the notion that income from a single asset is sufficiently secure that further asset diversification is not necessary to support borrowing. ${ }^{1}$

Even if corporations are involved as equity participants in a project financed entity, they typically limit their exposure to subsequent capital contributions. These arrangements are called non-recourse project finance. We will use the general term to cover this case as well. 
In the electric utility industry, investor owned utilities (IOUs) sell bonds or borrow from banks based on the revenues associated with assets in the transmission and distribution functions of their business as well as from the wholesale generation segment. Private power producers, by contrast, generally finance projects on a stand-alone basis. The credit support for project finance comes in large part from the power purchase agreement between the project developer and the purchasing utility. This agreement reduces most of the risk that the project will not find a buyer for its product. ${ }^{2}$ The power purchase agreement not only provides a guaranteed purchaser but also incorporates pricing terms. This makes for an extremely secure market. Because the security provided by power purchase agreements occurs relatively infrequently in markets, most project finance is associated with power generation (Kensinger and Martin, 1988).

The lender's problem in the case of project finance is to assure that revenues from the single asset will be sufficient to repay the loan. Ultimately, repayment depends upon the economic viability of the project. The power purchase agreement assures that there will be a buyer for the project output at specified prices and performance levels. The lender must be assured that costs will be sufficiently below revenues to generate enough cash to meet debt service payments with an acceptable margin. We will discuss this concept in Section 3 below. A fundamental component of the credit review process is to assure that performance requirements, which are always part of the power purchase agreement (Kahn 1991), can be met by the project developer. To provide this assurance, lenders include extensive restrictions, called loan covenants, in their agreement with borrowers. Broadly speaking, the loan covenants restrict the borrower's freedom of action in ways that help assure the lender that not only will things work as expected, but that prudent measures have been taken to deal with possible adversities. Corporate bonds typically have a set of restrictive covenants (Smith and Warner, 1979). Loan covenants in project finance are generally more restrictive than those found in bonds. Details on these terms for private power projects are reviewed extensively in Kahn et al (1992).

In this discussion, we focus primarily on quantitative aspects of project finance. We concentrate on the notion of "debt capacity" of projects. This notion is formalized in various ways in the academic literature; the most typical being from the perspective of maximizing the value of the firm (see Bergman and Callen, 1991). We will use the term "debt capacity" in a very simple way, meaning only that project developers seek to maximize the fraction of debt in the capital structure of their projects, subject to the constraints that lenders will tolerate. This definition is consistent with industry practice. The quantitative measure of lenders' willingness to loan is the debt service coverage ratio, defined in Section 2.3.1 below. This ratio is determined in part by the terms, i.e. loan maturity and interest rate, that lenders offer to the project.

The remaining risk is that the regulator of the utility will disallow the costs associated with the purchase. In this case payments may be reduced or the contract terminated, if there is a "regulatory out" clause in the contract. These events are only likely to occur if the underlying economics of the project are not favorable. 


\subsection{Capital Structure}

The term capital structure refers to the mix of debt and equity that is used to finance projects or firms. There is a substantial literature, primarily in the context of firms, addressing the determinants of capital structure. Harris and Raviv (1991) is a review of recent theoretical literature, which omits the empirically important topic of taxation and its role. The influence of taxes on capital structure is examined by Bradley, Jarrell and Kim (1984), who also report some statistical results on how capital structure varies across industries. Despite the considerable attention given to this subject, Brealey and Myers conclude their standard textbook with the observation that no coherent theory of capital structure yet exists (1991, p. 922).

The elements of the capital structure problem which concern us are few. Primary among them is the fundamental conflict between debt and equity investors (see Myers, 1977 for example). The debt contract is a fixed obligation between the borrower and the lender. The debt investor does not profit, beyond a certain level, from project success. She will, however, share in project failure if returns are not sufficient to meet contractual debt requirements. Therefore, the debt investor must seek a high probability of project success. As Stiglitz and Weiss (1981) have shown, this can lead to credit rationing. ${ }^{3}$ Equity investors, by contrast have limited liability for project losses, but unbounded returns from project success. Therefore, equity investors seek more risk than debt investors. The proportion of debt and equity in the capital structure of a firm will vary with the investment opportunities and market structure within which firms operate.

\subsubsection{Debt}

There is a wide variety of debt contracts. Fabozzi and Pollack (1987) review the variations extensively. We focus on three principal features of loans. These are: (1) the interest rate, (2) the maturity and (3) the expected debt service coverage. We will discuss each of these briefly; in particular, we emphasize how these features are treated in project finance for electric power.

\section{Interest Rate}

All lenders charge interest. The rate charged for particular loans depends upon both the maturity (or length) of the loan and its risk. The relationship between interest rates and maturity is called the term structure of interest rates. All other things equal, the typical relationship between interest rates and loan maturity is positive, i.e. longer term loans bear higher interest rates.

In credit markets, you cannot simply raise price (i.e. the interest rate) to ration efficiently. By raising the interest rate to borrowers, lenders simply induce them to undertake riskier projects, which decreases the probability of repayment. This is why lenders ration credit. 
The risk of default is also reflected in interest rates. Up to the limit of unacceptable risk (where credit is rationed) interest rates rise with default risk. For publicly traded bonds, there are independent agencies which assess default risk and assign credit ratings which indicate the relative risk. Investor owned electric utilities use bond finance as their primary form of debt. These bonds are routinely rated by the credit agencies. Private power projects have relied more on bank debt or other forms of private borrowing. These loans are not publicly rated, but the same pricing principles apply. Higher risk means a higher interest rate. Recently, the private power industry has begun to sell bonds, and has therefore been subject to review by the credit rating agencies. Standard and Poor's (1991) is a good summary of the risks associated with private power from the lender's perspective.

One important aspect of loan risk for our purposes is the uncertainty due to technology. If a given technology is viewed as having a particularly greater performance risk than the norm, a risk premium will be charged by lenders for firms that are dependent on that technology. Risk perceptions change with experience, sometimes decreasing as technology matures, sometimes increasing as unanticipated problems emerge. In the electricity industry, nuclear power has been subject to technological risk premia in the financial markets. Barrett et al (1986), for example, showed that prices for public utility bonds dropped differentially for companies with nuclear power assets after the Three Mile Island accident, widening the risk premium. Wind turbine projects must also deal with perceptions of technological risk, and the added returns that debt investors will require to accept them.

\section{Loan Maturity}

Typically, loans mature at a time determined at the outset of the lending agreement. The maturity, or term of a loan is negotiated between borrower and lender for reasons of their own. Loan maturity is sometimes used as a method of controlling risk. Lenders may hedge their commitments to projects by lending only for relatively short periods of time. Corporate borrowing is frequently done on a continuous roll-over basis. This means that when loans mature, they are replaced by new borrowing that maintains the capital structure. The diversity of corporate assets makes such a financial policy feasible. Lending is not tied to the economic lifetime of one particular asset. In the case of project finance, however, the limiting factor on loan term is the term of the power purchase contract. These loans must be amortized over their term, and rolling over is not an expected outcome. ${ }^{4}$

Investor owned and government owned utilities borrow on a roll-over basis. This means that they effectively do not make principal payments when they borrow. Their primary form of debt is publicly traded bonds. In the typical corporate bond contract, the principal amount is due entirely upon maturity (this is like a balloon mortgage). When a utility bond matures, it is replaced by a new bond issue. The principal from the new issue is used to pay off the maturing bond. Since this happens essentially forever, it is equivalent to never making

4 This is not to say that refinancing of loans does not occur, nor that these opportunities are not considered by all parties. Compared to corporate finance, however, these opportunities are much more limited. The term of the power purchase contract still acts as the ultimate constraint on re-financing. 
principal payments. By contrast, project finance debt (whether bonds or bank loans) involves amortization payments. The shorter the debt maturity, the greater is the burden of these principal payments.

\section{Debt Service Coverage}

This term refers to the cash available to the firm or to a project financed entity to pay the principal and interest on its debt. It is usually expressed as a ratio of the available cash to the total debt service (i.e. principal plus interest). In accounting terminology the numerator in this ratio is pre-tax income plus depreciation and interest. If the debt is a typical corporate bond, only the interest payment shows up in the denominator.

The credit constraint can be expressed in a number of ways. They all involve a minimum acceptable value for the debt service coverage ratio. These minima may be measured for the early years of the project (when cash flow is frequently most constrained), as an average value over the term of the loan, or both. Since these ratios are based on projections of costs and revenues, lenders will examine their sensitivity to changes in assumptions such as project performance, cperating costs, or revenue forecasts. The only sensitivities of interest to lenders are "worst case" outcomes, since it is these which threaten repayment. The emphasis on worst case outcomes is one of the ways in which the lender's conflict with the equity investor appears in practice.

Standards for debt service coverage fluctuate over time. When credit is easy, these standards are more lax. Conversely when credit is tight, required debt service coverage ratios increase. For project finance, the debt service coverage ratio can never be below 1.0 . If it were expected to be, then debt service could not be paid, and therefore the lender would require more equity from the project sponsor. The requirements for adequate debt service coverage illustrate the sense in which capital structure is endogenous to project economics. Developers will want to maximize debt in the capital structure to lower overall financing cost (since debt is cheaper than equity) but the debt fraction is limited by debt service coverage requirements. Depending on how much revenue the project can produce relative to cost, the project can carry more or less debt. The objective of maximizing debt is also consistent with maximizing the returns on equity, since increasing leverage raises equity returns, compared to a case of lower debt.

\subsubsection{Equity}

There is little if any difference between equity investment in a corporate or a project financed structure. In both cases, equity represents a residual claim on all surpluses generated by the firm or the project. The amount of equity in the capital structure of a firm or in a project finance structure is a residual to the amount of debt and the capital requirements of the enterprise. 
Equity investment finances project costs in the period before any return can be anticipated. This is why it is risky. No one really knows whether the project will result in a viable commercial activity.

Equity returns come in two forms: direct cash flow and tax shield. Unlike interest rates for loans or bonds, there is no transparently simple way to measure the "cost" of equity capital. Indeed, there is a large literature devoted to this subject. A good survey of this literature with applications to public utilities is Kolbe et al (1984).

\subsection{Tax Issues}

Taxes are ubiquitous in economic activity. Their impact on powerplant economics, including wind turbines, has been studied recently by Hadley et al (1993). The relevance of taxes for financing is more limited than the broader issue of project economics. We discuss the tax issues related to financing separately for debt and equity. In the case of wind turbines, it is important to understand the role of the production tax credit of $1.5 \mathrm{k} / \mathrm{kWh}$ available for 10 years which was recently created as part of the Energy Policy Act of 1992.

Debt

The deductibility of interest payments with respect to corporate income taxes is of fundamental importance. This feature of the tax code creates an incentive toward debt financing. There are off-setting effects involving personal taxes, but these are generally not as large. Brealey and Myers (1991, chapter 18) discuss these issues.

The production tax credit has no effect on debt capacity because it is not a cash asset accruing to the project, but only an offset to taxes on equity. The existence of this credit has no effect on debt service coverage, since taxes do not figure in lenders' calculation.

Equity

The federal tax code includes a feature known as the Alternative Minimum Tax (AMT). The purpose of this feature is to ensure that corporate and high income non-corporate entities that benefit from tax preferences (such as accelerated depreciation and tax credits) pay a minimum amount of income tax. Hadley et al (1993) found that AMT had an enormous negative impact on the equity returns for project financed wind projects, but minimal impact on the returns for project financed combined cycle projects (see Table 6.3). Even without the AMT, projects may have to carry tax losses forward until such time as there are enough taxable profits to offset them. One of the most striking results in the wind turbine case was that some of the production credits were never used, because the projects never generated enough income to absorb them. 
These results must be considered very carefully because the Hadley et al study does not use a very sophisticated characterization of project financing. These authors use a standard capital structure for all private power projects. This structure is $80 \%$ debt and $20 \%$ equity. While this characterization is a reasonable summary of practice for conventional technology, it may not reflect practice for renewable energy projects. Indeed the problems discovered concerning the vulnerability of equity returns to AMT suggests that developers will find a way to capture the tax benefits. This subject will be investigated further.

\subsection{Measures of Financing Cost}

In this section, we define two measures of financing cost that will be used to compare the terms on which wind turbine and conventional powerplant are financed. These two measures are: (1) the weighted average cost of capital (WACC), and (2) the capital recovery factor (CRF). These are standard concepts that are commonly used. They are convenient measures of financing cost for use in economic modeling.

\section{Weighted Average Cost of Capital}

The weighted average cost of capital (WACC) just reflects the capital structure. The only difference between WACC as it is commonly used and a simple weighted average is the treatment of the income tax deductibility of interest payments. The standard expression for WACC is given by the following expression.

$$
W A C C=y * c+x * i(1-t)
$$

where $\quad y=$ portion of equity in the capital structure,

$c=$ cost of equity (after tax),

$\mathrm{x}=$ portion of debt in the capital structure,

$i=$ cost of debt,

$t=$ tax rate.

This expression for WACC is cited in standard texts, such as Brealey and Myers (1991, p.465). In some uses of this term, the tax shield associated with debt, the factor (1-t) is not used.

\section{Capital Recovery Factor}

The capital recovery factor is useful to capture the effect of loan maturity on the cost of financing. This can reveal significant differences in financing burden where projects have substantially different amortization schedules. The standard expression for CRF is given by 


$$
C R F=\frac{r(1+r)^{n}}{(1+r)^{n}-1}
$$

where $\quad r=$ the return on capital, i.e. WACC,

$\mathbf{n}=$ the amortization period.

We will use CRF (based on the appropriate WACC) as the summary statistic to measure financing cost for wind turbine plants and their competitors.

\section{3 - Empirical Measures of Financing Terms}

\subsection{Data Availability and Method of Approach}

The major difficulty involved with studying financial aspects of the private power market is the confidentiality of data. Since most project finance lending is placed privately with bank or institutional investors, rather than with public bonds, access to terms and conditions is limited. We will rely on a range of data sources of varying degrees of explicitness. The specific transactions referred to have occurred over a period of time during which capital market conditions have varied. Therefore some normalization procedures will be required. The objective is to use all available sources of data to synthesize a characterization that is more complete than any single transaction described, but nonetheless representative.

In section 3.2 we survey recent information about the financing terms of private power projects. The data comes from a variety of sources, and is typically incomplete with respect to the full range of information about particular transactions. Because of the incompleteness of the data summarized in Section 3.2, and problems of comparability across the examples, it is necessary to normalize. The normalization issues are discussed in Section $\mathbf{3 . 3}$ for interest rates. Section 3.4 discusses empirical approaches to estimating the cost of equity capital for private power producers using stock market data. The approach used in this section is the most reliable method for estimating the cost of equity capital among available procedures. Section 3.5 takes the normalized financial parameters and applies them to the formulation for measuring financing costs developed previously. Section 3.6 summarizes results.

\subsection{Recent Transactions}

This section summarizes recent data on the financial structure of private power projects. In Section 3.2.1 we discuss recent transactions involving wind turbines. Section 3.2.2 discusses recent transactions involving conventional fossil technology. Principal attention is devoted to projects using bond financing because the disclosure is most complete in such cases. Section 3.2.3 summarizes information from a variety of sources about financial terms for private 
power projects generally. The material in Section 3.2.3 does not describe specific transactions in as much detail as in the two previous sections, but does provide additional perspective on the project finance market. The goal of this entire section is to provide a basic picture of five variables: (1) capital structure, (2) cost of debt, i.e the interest rate, (3) the maturity of debt, (4) the required debt service coverage ratios and (5) the cost of equity. We want to produce such estimates for both wind and conventional technology. This information will be used to develop standardized comparisons after we make some normalized comparison of costs across the rather eclectic range of data sources. Because the cost of equity capital is not directly observable (in the way that an interest rate is observable), we will defer its discussion to until Section 3.4 below.

\subsubsection{Wind}

This section characterizes two recent project financings for wind energy turbines. The data is based on press releases from the developers. These are the only such projects in the past several years.

\section{Kenetech/LG\&E Energy}

A project financing for wind turbine technology was announced in January, 1994 based on contracts between Kenetech and two utilities, Southern California Edison (SCE) and Northern States Power (NSP). The most complete discussion of this arrangement is contained in a short article appearing on January 12, 1994 in the Daily Journal of Commerce. According to this article, the capital structure of the project is $50 \%$ debt and $50 \%$ equity. The equity investors include LG\&E Energy Corporation as well as Kenetech. John Hancock Mutual Life Insurance is the lender. The term of the debt is for twelve years. No interest rate was quoted in the article. This source seems to indicate a total capacity of $64 \mathrm{MW}$ and a total cost of $\$ 82$ million. This implies a cost of about $\$ 1280 / \mathrm{kW}$. Essentially the same information was contained in a monthly trade publication Independent Energy (v.24, no.4 (1994) p.48) except that no information about capacity is given. These projects are mentioned in the prospectus offering shares of common stock in Kenetech Corporation, but that source suggests only $44 \mathrm{MW}$ total capacity, 19MW for SCE and 25MW for NSP (Kenetech, 1993). By the time the financing took place, the project was expanded to $67 \mathrm{MW}$, resulting in an implied cost of $\$ 1220 / \mathrm{kW}$ (Wong, 1994).

\section{Cannon Power Corporation}

In February, 1994 the Wall Street Journal announced a $\$ 19,750,000$ senior secured loan from Heller Financial to the Cannon Power Corporation for a wind turbine project to be built in Tehachapi, California. This announcement gave no details concerning the term of the loan, its interest rate, or the capital structure of the project.

The project is referred to in Gipe (1994 p.91), where its size is reported to be $14.5 \mathrm{MW}$. If we assume at least $20 \%$ equity, then the total deal is $\$ 24$ million, and the unit cost is $\$ 1650 / \mathrm{kW}$. This is roughly comparable to the costs implied by the Kenetech/LG\&E project. 
If we assume that this project is eligible for tax incentives, such as the production tax credit, then the equity fraction of the capital structure may well have to be larger than $20 \%$. The reason for this is limits on the ability of projects with only $20 \%$ equity to absorb the full value of the tax incentives.

\subsubsection{Conventional Fossil}

This section describes the financing arrangements for two gas-fired electric generation projects. These two projects were financed with public bonds. The information is based on the disclosures in the bond prospectuses.

\section{Sithe Independence}

The Sithe Independence Cogeneration Project is a $1000 \mathrm{MW}$ gas fired combined cycle project located in upstate New York. In January, 1993 the project sold $\$ 717$ million in bonds to finance construction. Very substantial detail on the structure of the project is contained in the prospectus advertising the sale of the bonds (Sithe/Independence, 1993). Additionally, the bonds were rated by the credit rating agencies, who provide additional information (Standard and Poor's, 1993).

Sithe/Independence is a very highly leveraged project. The capital structure includes $7.8 \%$ equity and $92.2 \%$ debt (Standard and Poor's, 1993). The debt is structured in three series of bonds, with increasing maturities and correspondingly higher yields. The first, which covers $22 \%$ of the total debt, has a 9 year maturity at an interest rate of $7.9 \%$. The second, which covers $21 \%$ of the total debt, has a 14 year maturity at an interest rate of $8.5 \%$. The third, which covers the remaining $57 \%$ of the debt, has a 20 year maturity at an interest rate of $9.0 \%$. The resulting weighted average maturity is 16.37 years, and the weighted average interest rate is $8.65 \%$.

Despite the very high leverage, the margin between costs and revenues is sufficiently large to support very substantial debt coverage ratios. Base case projections result in minimum coverage levels of $1.89 \mathrm{x}$, and weighted average of $2.95 \mathrm{x}$ over the lifetime of the securities. Worst case analysis resulted in minimum coverage levels of $1.3 \mathrm{x}$ and average $2.2 \mathrm{x}$ over the lifetime of the securities (Standard and Poor's, 1993, pp.73-77).

\section{Central Valley Financing Authority}

The Central Valley Financing Authority (CVFA) is a joint action agency set up by the Sacramento Municipal Utility District (SMUD) and the Sacramento Regional County Sanitation District to finance, construct and own a $99 \mathrm{MW}$ cogeneration project using sludge digester gas (15\%) and natural gas $(85 \%)$ to produce power for sale to SMUD. The sales of $\$ 143.2$ million in bonds will finance construction and repay SMUD's \$13.4 million equity 
contribution. The capital structure, therefore is about $9 \%$ equity and $91 \%$ debt. ${ }^{5}$ Strictly speaking, however, the project is $100 \%$ debt financed, which is characteristic of public power generally. The average maturity of the bonds is.about 20 years.

The debt service coverages in the base case are $1.31 \mathrm{x}$ minimum and average $1.41 \mathrm{x}$. In the worst case the minimum is $1.02 \mathrm{x}$, and the average is $1.07 \mathrm{x}$. Despite the very low coverages in the worst case, these bonds received an investment grade rating because the low coverage case is quite unlikely, and the power pricing terms contain substantial protection for the debt service (Standard and Poor's, 1993, pp.53-55).

Since these are tax exempt bonds, their pricing terms are subject to different supply/demand relations than ordinary taxable debt. The transaction, therefore, is more interesting for our purposes for its structure than for its pricing.

\subsubsection{Other Information Sources}

\section{Public Debt Offerings}

A recent review of project finance bond offerings is contained in Bispham (1994). In Table 1 , we summarize his results as well as two recent corporate bond offerings by private power firms. Bispham uses the average maturity on the Sithe/Independence bonds, which is slightly shorter than the maturities cited in Section 3.2.2 above, because these bonds are amortized five years before the final maturity date. We also include data on the Hardee project cited in this paper even though its debt was placed privately. The final column in Table 1, Spreads over Treasuries, refers to the interest rate premium, expressed in basis points (where 100 basis points equals $1 \%$ ), over Treasury bonds of the same maturity. The data in this table will be discussed in greater detail in Section 3.3 below.

Table 1. Private Power Debt Financing

\begin{tabular}{|c|c|c|c|}
\hline $\begin{array}{l}\text { Tssuer } \\
\text { Type }\end{array}$ & Issuer & Average Term & Spread over Treasuries \\
\hline \multirow[t]{5}{*}{ Project Finance } & Subic Power & 8.0 & 385 \\
\hline & Sithe/Independence & 7.1 & 170 \\
\hline & & 12.5 & 195 \\
\hline & & 18.3 & 168 \\
\hline & Hardee Power & 12.1 & 100 \\
\hline \multirow[t]{2}{*}{ Corporate Bonds } & Cogentrix & 10.0 & 110 \\
\hline & California Energy & 10.0 & 325 \\
\hline
\end{tabular}

5 The capital structure can be computed either assuming the equity contribution is incremental to the debt (so equity fraction is $13.4 / 157.6=0.085$ ); or, since the CVFA debt reimburses SMUD equity, we could call the structure $9.4 \%$ equity $(13.4 / 143.2)$ and $90.6 \%$ debt. 


\section{Trade Literature}

There is a literature describing project finance activity which is less specific than that associated with particular transactions, but which reflects a professional consensus on the broad parameters associated with financing terms. Hoffman's (1993) survey, for example, lists a number of generic conditions for private power project finance. These include: (1) minimum equity of $10 \%,(2)$ expected debt service coverage ratios of $1.4 \mathrm{x},(3)$ maximum debt maturity of 15 years.

Another interesting source is the Infocast newsletter Project Finance Monthly. This publication includes a feature known as "Project Finance Market Wire," which quotes market participants on a "not for attribution" basis. Selected discussions from this newsletter include the following characterizations of financing terms for conventional private power projects. The July, 1991 issue contained the following summary: (1) equity at 10-20\% of total capital, (2) debt maturities of 15 years including construction, (3) minimum coverage ratios of 1.25 1.3, and (4) risk premium of 75 basis points above cogeneration (Project Finance Monthly, 1991). In August, the Infocast newsletter 1992 characterized the kinds of returns available to "passive equity." The range quoted went from 10-15\% (Project Finance Monthly, 1992). More recently, the June 1993 issue of this newsletter quoted the interest rate spreads on project finance senior debt of "LIBOR plus 125-150 basis points" and target coverage ratios of 1.3 (Project Finance Monthly, 1993a). Finally, the September 1993 issue briefly characterized the risk premium on senior debt at about 75 basis points (Project Finance Monthly, 1993b).

\subsection{Normalization Issues for Interest Rates}

Given the thin sample of available data, and the changes in financial market conditions over the period during which the transactions occurred, it is necessary to normalize the data reported in Table 1 so that standard relationships can be developed. We break down the structure of interest rates into a term structure component, reflecting maturity, and a risk premium.

Before discussing these procedures, it is necessary to discuss some terminology that arises in the financial publications. Of particular concern is the citation of LIBOR as the benchmark for loan pricing. LIBOR, or the London Interbank Offering Rate, is a variable interest rate used in the Eurodollar markets. Although spreads are usually quoted against LIBOR, what usually happens is that projects finance with fixed rate debt by using derivative instruments such as "swaps" which convert the variable rate loan to a fixed rate loan. We will use the convention of specifying interest rates as a spread over the Treasury bond of the appropriate maturity. The spreads relative to LIBOR will be the spreads we use relative to Treasuries. The cost of the swap between LIBOR and Treasuries is assumed to be embedded in the difference between LIBOR rates and the corresponding Treasury rate. This introduces an 
underestimate of the cost of debt, since it neglects the cost of the swap. Since we have no estimate of this cost, this error is inevitable, but it affects both wind and conventional projects equally, so its effect is minimized.

\subsubsection{Term Structure of Interest Rates}

The term structure of interest rates is not an economic invariant. Although the typical relationship between interest rate and debt maturity is positive (i.e. an upward sloping yield curve), this is not always the case. Historical studies over long periods of time have detected a cyclical pattern in the term structure (Cagan, 1966; Kessel, 1965). For our purposes we rely on recent credit market experience.

From the Sithe/Independence data, we observe a $0.1 \% / y r$ increase in yield over the range 920 years of maturity. Bispham's (1994) summary of the Treasury bond market is also consistent with this estimate for 5 to 10 year maturities, and about half that in the 10 to 30 year range. These estimates show that the term structure effect is relatively small.

\subsubsection{Risk Premium}

We use the term "risk premium" to refer to the additional yield require on debt for projects that have a higher probability of default than some given standard. For our purposes we will use conventional fossil power projects which have high coverage ratios as the standard of comparison. Just as in the case of the term structure, risk premia vary over time, depending upon economic conditions. Jaffe (1975) studies risk premia relative to the business cycle. Johnson (1967) studies both business cycle effects and term structure effects on risk premia.

There appears to be a difference between the use of the term "risk premium" in the "not for attribution" literature and in the "deal-specific" analysis. In the former context, the risk premium is estimated at 75 basis points or less. But looking at Subic (Bispham, 1994) and California Energy vs. Cogentrix, a spread of 200 basis points seems to emerge. In the latter two cases, there is something beyond ordinary business risk being priced. In both Subic and California Energy there is a foreign country element (in both cases it is the Philippines). Pricing these loans involves estimating the credit of the Philippines government. Additionally, California Energy has resource risk associated with geothermal energy. It is also much more highly leveraged than Cogentrix. 


\subsection{Cost of Equity}

\subsubsection{Conceptual Basis}

There is no simple transparent measure of the cost of equity capital that corresponds to the interest rate on debt. To measure the cost of equity capital it is necessary to use stock market data and analytic procedures to infer the cost. There are a variety of procedures used by financial analysts and academic investigators. We rely on the Capital Asset Pricing Model (CAPM). CAPM is a well-defined model that is grounded in economic and financial theory. Based on an equilibrium model of investor behavior and market valuation, standard business school textbooks on corporate finance favor this approach.

The principal advantage of CAPM is that it provides a precise and measurable definition of risk as applied to stocks. The risk measure, called beta, is proportional to the correlation between the rate of return of a particular asset with the rate of return for the market as a whole. The proportionality constant is the ratio of the standard deviation of the asset's rate of return to the standard deviation of the rate of return for the market as a whole. This measure of risk is then related in a straight-forward fashion to the cost of equity capital through the basic CAPM equation as follows

$$
r_{e}=E\left(r_{j}\right)=r_{f}+\beta_{j} \cdot\left[E\left(r_{m}\right)-r_{f}\right],
$$

where $E\left(r_{j}\right)=$ the expected rate of return on asset $j$ (i.e. the cost of equity capital),

$r_{\mathrm{f}}=$ the current risk-free rate of return,

$\beta_{j}=$ the risk measure for asset $j$,

$E\left(r_{m}\right)=\quad$ the expected rate of return for the market.

CAPM asserts that the expected rate of return is just the risk-free rate, $r_{\mathfrak{f}}$ plus a risk premium that is given by the risk measure, $\beta$, multiplied by "the market price of risk" (MPR). The MPR is the bracketed term in the CAPM expression, namely the difference between the expected rate of return for the market as a whole and the risk-free rate of return.

CAPM has a number of problems in the translation from theory into practice. Difficulties arise in the estimation of all its parameters. Empirical tests of CAPM have been ambiguous. A number of adjustments or re-formulations of CAPM have been proposed. Despite these issues, CAPM remains the most straight-forward and widely used quantitative tool for estimating the cost of equity capital. Alternative models, such as the discounted cash flow (DCF) model rely on dividend history of the companies involved. For private power companies there is little history of this kind. This makes DCF an inapplicable option. 


\subsubsection{Empirical Approach}

We will apply CAPM to data on the stock prices of three companies that are "pure plays" on the private power industry, i.e. they are engaged only in this business. Two of these companies rely only on conventional power generation technology. The companies are AES Corporation (listed on the NASDAQ) and Destec (listed on the NYSE). The third company, Kenetech, is primarily a developer of wind power projects, although they do have other energy related activities (Kenetech, 1993).

The risk measure, $\beta$, that is the fundamental feature of CAPM is measured by regressing the returns of asset $j$ on the returns of the market portfolio, usually represented by the S\&P 500 index (Benninga, 1990). Using the S\&P 500 index to represent the market portfolio, we estimate the betas of our three independent power producers. ${ }^{6}$ The results are summarized in Table 2 below. We include in this table an indication of the statistical validity of the beta estimate, which is the $t$-statistic of the regression equation. These $t$-statistics are significant at a confidence level greater than $95 \%$.

A large beta for Kenetech is not inconsistent with other beta estimates for technology oriented industries. For example, Brealey and Myers (1991, p.143) citing estimates from Merrill Lynch for the period 1984-1989, give beta estimates of 1.30 for Digital Equipment, 1.40 for Genentech, and 1.69 for Tandem Computer. The low beta stocks cited there include: AT\&T at 0.76 , Bristol Myers Squibb at 0.81 and Exxon at 0.67 .

\begin{tabular}{|c|c|c|}
\hline Fim & Estimate & Trstatistic \\
\hline AES Corporation & 0.85 & 4.16 \\
\hline Destec Energy & 0.52 & 3.60 \\
\hline Kenetech & 1.59 & 3.52 \\
\hline
\end{tabular}

To apply the beta estimates to the CAPM cost of equity capital equation, we need estimates of the other parameters. Brealey and Myers (1991, p.131) suggest that the risk-free rate be estimated from the interest rate on short term Treasury bills. For the expected risk premium, $E\left(r_{m}\right)-r_{\mathfrak{f}}$ they suggest using a long term estimate equal to $8.4 \%$. This is the average return on common stocks in excess of the risk-free rate estimated over an approximately sixty year period (Tbbotson, 1989). We use $4 \%$ for the risk-free rate of return (which is the short-term Treasury bill rate), the estimated betas and a risk premium of $8.4 \%$ to estimate the cost of equity for our three private power firms. The results are summarized below in Table 3.

The regressions used daily returns. For Kenetech we had 197 data points from 9/22/93 to 7/05/94. For AES we had 763 data points from 6/27/91 to $7 / 05 / 94$. For Destec we had 781 data points from 6/3/91 to 7/5/94. 
Table 3. The Cost of Equity

\begin{tabular}{|c|c|}
\hline Finn & Costror Equiti \\
\hline $\begin{array}{l}\text { AES Corporation } \\
\text { Destec Energy } \\
\text { Kenetech }\end{array}$ & $\begin{array}{c}11.14 \% \\
8.37 \% \\
17.36 \%\end{array}$ \\
\hline
\end{tabular}

The results in Table 3 are broadly consistent with views expressed in the trade press about the cost of equity capital for wind turbine projects. For example, Bodington (1994) cites a transaction involving new equity for a "construction phase" windpower project having an "expected return of 18-20\%." The concept of "expected return" is not quite the same as cost of capital. The latter notion is really the minimum required return, whereas "expected return" would involve something more than the minimum. Nonetheless, given this relationship, the Table 3 results for wind turbines are not inconsistent with trade literature. They show that the risk associated with equity investment in wind turbine projects requires at least a $600(17.36 \%$ $-11.14 \%=6.22 \%$ ) basis point greater return than what is required by conventional technology.

It should also be said that the three companies examined here have differences in their activities and asset portfolios that make the comparison we are making here a little problematic. In particular, AES and Destec have a much larger percentage of operating projects than Kenetech. All things equal this should lower their risk, since the risk in operating projects is lower than that for development. Furthermore, there may be a difference in risk for Kenetech shareholders and for investors in a wind project. Lacking any basis for separating these, however, we must settle for identifying them as a first approximation.

Finally, something needs to be said about the interpretation of these results. Why should "technology risk" show up in the CAPM framework? CAPM measures the correlation of individual security returns with the overall movement of the market. Perhaps the explanation is that technology failure is much more serious if it occurs in a recession, and success more profitable during expansions. An alternative theory, in the case of wind power, would be that willingness to pay for environmental benefits increases during expansions and goes down during a recession.

\subsection{Measuring Financing Cost}

To develop measures of financing cost for conventional and wind turbine technology, we rely on four principal parameters: (1) interest rate on debt, (2) debt maturity, (3) capital structure, i.e. the fraction of debt and equity, and (4) the cost of equity capital. The debt coverage ratio is embodied implicitly in this characterization through its effect on capital structure. 
For the wind turbine case, we assume 12 year debt maturity at an interest rate of $10 \%$. The cost of equity capital is assumed to be $18 \%$. We test two different capital structures. The more favorable assumes $35 \%$ equity and $65 \%$ debt. Given the result cited in Hadley et al (1993), that wind turbine projects capitalized with only $20 \%$ equity could not absorb all available tax credits, we use more equity to meet this opportunity. We choose a value intermediate between Hadley's case and the Kenetech/LG\&E transaction described in Section 2.1 above. The second capital structure, which is the same as the Kenetech/LG\&E, uses $50 \%$ debt and $50 \%$ equity.

For the conventional technology we assume a slightly longer debt maturity of 15 years. We use a $9.5 \%$ interest rate. This assumes a 75 basis point risk premium on wind, which is at the low end of the range discussed previously, offset by the longer maturity premium of about 25 basis points. The net result is an interest rate that is $\mathbf{5 0}$ basis lower for the conventional technology. For the cost of equity capital, we use $12 \%$, which is on the high side relative to our CAPM results. What is important is the spread between equity costs for conventional and wind turbine technology, which at 600 basis points is consistent with our CAPM results.

Table 4 presents results using the definitions of WACC and CRF described previously. We calculated CRF using the different debt maturities for each project. This results in a slightly higher burden on the wind project (with the shorter debt maturity) than the conventional technology. It is reasonable to use the different maturities because they reflect financing constraints, which is the object of the inquiry. Using other measures, such as contract lifetime, would measure economic costs, which differ from financial costs.

The Table 4 results show a significantly greater financing cost for wind turbines than conventional technology. Comparing $\mathrm{CRF}$ in the high equity case, we find a financing cost that is $46 \%$ greater than conventional technology. For the low equity case, the premium is $34 \%$. The cost of equity and the larger equity fraction are the primary causes of the higher financing cost. The differential would have been even higher had we used a larger risk premium on debt for the wind turbine projects. A larger risk premium may well be justified.

Table 4. Financing Cost Comparisons

\begin{tabular}{|c|c|c|c|c|c|}
\hline Techology & $\begin{array}{l}\text { pebrequig } \\
\text { Percentage }\end{array}$ & Debtcost & Equity $\rho_{0 s t}$ & $14 \mathrm{se}$ & QRF \\
\hline Wind & $\begin{array}{l}65 / 35 \\
50 / 50\end{array}$ & $\begin{array}{l}0.10 \\
0.10\end{array}$ & $\begin{array}{l}0.18 \\
0.18\end{array}$ & $\begin{array}{c}0.1046 \\
0.122\end{array}$ & $\begin{array}{l}0.150 \\
0.163\end{array}$ \\
\hline $\begin{array}{l}\text { Conventional } \\
\text { Fossil }\end{array}$ & $80 / 20$ & 0.095 & 0.12 & 0.0726 & 0.1116 \\
\hline
\end{tabular}




\subsection{Summary}

The principal result of this section, the substantial financing burden of wind turbine projects compared to combined cycle technology, stems primarily from the risk premium in the equity markets. The statistical analysis in Section 3.4 shows a cost of equity premium of approximately 600 basis points for Kenetech (the wind turbine manufacturer/project developer) versus Destec and AES Corporation, which develop conventional technology projects. This is consistent with trade literature estimates. Not only is the cost of equity higher for wind turbine projects, the capital structure of these projects requires more equity relative to debt. This capital structure effect is driven largely by the tax credit. It will be examined in more detail in Section 4 below. The capital structure effect reinforces the equity risk premium in the total financing cost. While there are effects of risk observable in the debt markets, they are much smaller. Wind projects pay slightly higher interest rates and use shorter debt maturities, but these effects are much smaller than the cost differences associated with the equity side.

\section{Economic Analysis of Empirical Results}

\subsection{Introduction}

The empirical analysis of financing costs for wind turbine projects compared to those using conventional technologies found a substantial (30-45\%) premium for the wind turbine technology. The primary contributors to this result were: (1) the higher cost of equity capital for wind, and (2) the larger fraction of the capital structure funded by equity. In this section, we concentrate attention on the second of these factors. Section 4.2 identifies the production tax credit as a key determinant of the capital structure. In Section 4.3 we present a simple model of the financial effect of converting the credit from a tax to a cash basis. In Section 4.4, the magnitude of financing cost reductions implied by a converting the production credit from a tax to a cash basis is estimated. Finally, Section 4.5 contains brief comments on the budgetary implications of changing the basis of the production credit.

\subsection{The Production Credit is a Financial Constraint}

A major driving factor on the capital structure of wind turbine projects is that the production credit is paid as a tax incentive rather than in cash. It is not clear why the tax incentive form was chosen for the subsidy. Indeed, the government pays many subsidies in cash rather than in the form of tax incentives. The agriculture and welfare programs are prominent examples.

The benefits of transforming the wind subsidy from a tax basis to a cash basis is that it would allow the capital structure to shift more toward the same kind of debt financing that 
conventional technologies use. Because the tax credit only benefits equity investors, it is useless for debt financing. The project itself never sees any actual revenue from the credit that could be used for debt service. Instead the benefits appear on the tax returns of the equity investors.

Since debt financing is so much less expensive than equity, there is a hidden cost to the tax credit. The tax credit provides part of the required return on equity, but it does nothing to bring the capital structure of wind projects more into line with the competing conventional alternatives. By converting the subsidy to a cash basis, the project will then be in a position to support additional debt from the incremental cash flow. This will reduce total financing cost by allowing a shift from high cost equity to lower cost debt. ${ }^{7}$

An alternative approach to easing the financial constraint posed by the tax credit would be to sell it for cash. This approach is being attempted by at least one developer, but no such transaction has been completed as yet (Caffyn, 1994). The legal status of such transactions is uncertain.

\subsection{A Model of the Bankability of a Cash Subsidy}

In this section, we construct a simple analytical model to illustrate the effects on financing costs of shifting the production credit from a tax credit to a cash payment. This model abstracts from the details of project financing for particular projects. Instead it simply assumes that the starting capital structure is fully optimized with respect to all constraints, and that inability to absorb all tax benefits is the driving factor behind the heavy weighting to equity in the capital structure. ${ }^{8}$ By converting the production credit to a cash revenue stream, we increase the debt capacity of the project. The model quantifies this effect.

Notation:

$\mathbf{x}_{1}=$ debt fraction in the base case
$\mathbf{t}=$ debt maturity
$\mathbf{I}=$ interest rate on debt
$\mathbf{y}_{1}=$ equity fraction in the base case
$\mathbf{c}=$ cost of equity
$\mathbf{t}_{\mathbf{x}}=$ tax rate

To assure lenders that a cash production credit was usable to cover debt service, the loan structure would have to specify that the government payments went directly into the same trustee account that received revenues from the power sales. This kind of arrangement is standard in project finance (Kahn et al, 1992).

8 This assumption may not be valid for the whole range of potential capital structures. The technological risk of wind turbine technology may require a greater equity fraction than conventional technology. The magnitude of this effect is difficult to estimate and has been neglected in this discussion. 
Then in the base case, we have the usual definitions of WACC and CRF, namely

$$
\begin{aligned}
& \mathrm{WACC}_{1}=\mathrm{y}_{1}^{*} \mathrm{c}+\mathrm{x}_{1}{ }^{*} \mathrm{i}\left(1-\mathrm{t}_{\mathrm{x}}\right) \text { and } \\
& \mathrm{CRF}_{1}=r(1+r)^{\mathrm{n}} /(1+r)^{\mathrm{n}}-1 \text {, where } r=\mathrm{WACC}_{1}
\end{aligned}
$$

We now introduce the production credit, which we call PC. EPAct authorizes this as a unit amount (per kWh) times the amount of energy produced. For simplicity we will assume that this is a fixed dollar amount over the term of the financing (i.e. we neglect its escalation with inflation). We want to find out how much incremental debt service, which we call $\triangle \mathrm{DS}, \mathrm{PC}$ could provide if it were a cash payment. This is given by:

$$
\begin{aligned}
& \triangle \mathrm{DS}=\mathrm{PC} \mathrm{MCR}, \text { where } \\
& \mathrm{MCR}=\text { minimum allowable debt service coverage ratio. }
\end{aligned}
$$

The debt service in the base case, $\mathrm{DS}_{1}$, is just the annuity payment on the total debt of the project at the loan interest rate over the debt term. Denoting the total project capital by $C$, then

$$
\mathrm{DS}_{1}=\operatorname{PMT}\left(\mathrm{x}_{1}^{*} \mathrm{C}, \mathrm{i}, \mathrm{t}\right) \text {. }
$$

With $\triangle \mathrm{DS}$ available to increase debt service (at an acceptable coverage ratio), the project can now bear more debt. The new level of debt service, $\mathrm{DS}_{2}$, is simply

$$
\mathrm{DS}_{2}=\mathrm{DS}_{1}+\Delta \mathrm{DS}
$$

Using this expression, it is simple to solve for the new debt fraction, which we call $x_{2}$. This is given by capitalizing $\mathrm{DS}_{2}$ to produce the new total project debt, dividing by total capital and simplifying (using the linearity of PV in PMT)

$$
\begin{aligned}
x_{2} & =P V\left(D_{2}, i, t\right) / C \\
& =x_{1}+P V(\Delta D S, i, t) / C
\end{aligned}
$$

We then get a new $\mathrm{WACC}_{2}$ and $\mathrm{CRF}_{2}$. The savings in financing cost is given by the ratio of $\mathrm{CRF}_{2}$ to $\mathrm{CRF}_{1}$. 


\subsection{Estimating the Magnitude of a Bankable Production Credit}

Using the model developed in the previous section, we estimate, for plausible parameters, how large an effect on financing cost a cash production credit could have.

For simplicity we will assume the following physical and economic parameters:

Cost of wind turbine capacity:

$\$ 1000 / \mathrm{kW}$

Annual hours of equivalent fullload operation:

$2200^{9}$

Total revenues from production credit:

$\$ 33 / \mathrm{kW}-\mathrm{yr}^{10}$

Minimum debt service coverage ratio:

$1.25 \mathrm{x}$

These parameters, together with the loan maturity and interest rate, determine the incremental debt fraction, i.e. PV $(\Delta \mathrm{DS}, \mathrm{i}, \mathrm{t}) / \mathrm{C}$. For our base case values for loan maturity and interest rate, the incremental debt fraction is about 0.18 . This increase in leverage is the reason that total financing cost goes down with a cash production credit. In Table 5 below we show the reduction in CRF for our high equity and low equity cases.

These results show an approximate $10 \%$ decline in financing costs due to the conversion of the production credit from a tax credit to cash. The largest sensitivity of these results to financial variables is illustrated in the table, that involves the extension of the debt maturity assumed from twelve to fifteen years.

An important sensitivity of these results involves the assumption involving the capital cost of the wind turbines. For capital costs higher (per unit of capacity) than those assumed, the financing benefit of a cash production credit will be correspondingly smaller.

Table 5. Financing Effect of a Cash Production Credit

\begin{tabular}{|c|c|c|c|}
\hline Toan & $\begin{array}{l}\text { Capital } \\
\text { Structure }\end{array}$ & $\begin{array}{l}\text { ncremental } \\
\text { Debtr raction }\end{array}$ & CRF $/ \mathrm{CRF}$ \\
\hline Base Case & $\begin{array}{l}\text { Low equity } \\
\text { High equity }\end{array}$ & $\begin{array}{l}0.1798 \\
0.1798\end{array}$ & $\begin{array}{l}0.901 \\
0.906\end{array}$ \\
\hline 15 Year debt & $\begin{array}{l}\text { Low equity } \\
\text { High equity }\end{array}$ & $\begin{array}{l}0.2008 \\
0.2008\end{array}$ & $\begin{array}{l}0.879 \\
0.872\end{array}$ \\
\hline
\end{tabular}

This is the estimate of annual equivalent full load production used by Pacific Gas and Electric (1993) in their recent solicitation for renewable energy projects. It is slightly higher than estimates cited in Cohen (1993).

10 This is just $\$ 0.015 / \mathrm{kWh}$ times 2200 hours per year. We neglect the escalation of the production credit with inflation. 


\subsection{Budgetary Implications}

Given the estimates of the previous section, that a cash based production credit would lower financing costs by as much as $10 \%$, the implications for the federal budget are worth mentioning. The simple point is that such a switch could not be expected to be fiscally neutral. The financial effect of changing the production credit would be the same for a fixed amount of wind turbine capacity. What would change, however, would be the amount of wind capacity installed. With lower financing costs, the market price of wind turbine electricity would go down. This would increase the market share of the resource and therefore increase the total payments under the production credit.

\section{$5 \cdot$ Conclusions}

The two main sources of higher financing cost for wind turbine powerplants compared to conventional alternatives are the higher cost of equity capital and the lower amount of debt in the capital structure of windpower projects. The argument in Section 4 addresses the production tax credit as one source of the capital structure problem. In this concluding section, we review other factors which may contribute to these results and which may change over time to reduce some of the differentials observed in Section 3.

In Section 5.1 we address technology risk. This is the fundamental factor driving all of the results in Section 3. Resource variability risk is defined and discussed in Section 5.2. Finally, in Section 5.3 we discuss utility financing as an alternative to project financing.

\subsection{Technology Risk Premium}

Wind power is a "technology play." The limited history of wind turbine technology in power generation applications creates substantial uncertainty for investors. The experience of development in the early 1980 s was not sufficiently positive to give investors confidence that actual performance would correspond to predictions made by developers. Cox, Blumstein and Gilbert (1991) review this experience with particular emphasis on California, where most of the development occurred. 11 They report the substantial gap between performance levels promised to investors compared to those actually achieved. This history is widely known in the investment community, and represents a risk that appears to be priced by the equity markets. 
The equity risk premium for wind power technology should be reduced over time as more experience is gained. It is difficult to estimate how much the equity risk premium will be reduced as more operating experience accrues. Some rough guidelines are possible. Even with good operating results in the next few years, wind turbine technology is still going to be considered a technology play. The best that can be expected is that its beta might decline to a level equivalent to high technology companies in other industries. From examples cited in Section 3.4.2 above, that might mean a beta of 1.3 compared to 1.6. Such a reduction would reduce the cost of equity by about 250 basis points ( 0.3 times the market price of risk, i.e. $8.4 \%$ ). While this is a significant reduction, it would not eliminate the financing cost gap.

It will probably take a very long record of experience, say ten years at least, before the perception of technological risk in wind turbine powerplants is eliminated from investors' minds. It is beyond the scope of this project to estimate how long a period will be required to achieve this result, or exactly what kind of performance level would be required. All that can really be said is that when such a state of technological maturity is reached, both the equity risk premium and the capital structure burden identified with wind projects today can be expected to disappear.

\subsection{Resource Variability Risk}

Apart from technology, there is a "resource risk" involved in wind power development. Wind is an intermittent resource, whose availability varies with meteorological conditions. Developers study various sites to determine the best locations for wind power projects, but there is inherent uncertainty in these measurements. There are different views about the relative magnitude of this risk and the technological uncertainties described in Section 5.1 above. The "resource" uncertainty is generally believed to be somewhat smaller than the technology risk, but it is not negligible.

Resource uncertainty has two important dimensions: (1) uncertainty about average windspeeds at a given site, and (2) uncertainty about minimum windspeeds at a given site. It is common to assess the economic viability of a wind site in terms of average windspeed. This is a measure of the amount of energy available to be captured and converted into electricity. In a project finance setting, however, minima are also important. The period of time over which minimum windspeed becomes important is approximately the annual cycle. The basic concern here lies in debt service requirements, and the vulnerability of the revenue stream to low resource availability over the annual cycle. If windspeed were low on average for a month or two, projects could meet their debt service costs through a "reserve fund" which typically has six months debt service available for such contingencies (Kahn et al, 1992). The real concern is a period of low wind availability that would exhaust the debt service reserve. a "wind drought." Hedging this risk in project financing would require a larger debt service reserve than for a project which did not face resource variability. We have not been able to determine if project finance wind projects have significantly larger debt service reserve requirements than conventional fossil projects. 


\subsection{Utility Financing}

This entire discussion has focused on project financing as the vehicle for developing wind power projects. While project financing by private producers has been the dominant mode of development, utility ownership is also possible. Of the "pending contracts" listed by Kenetech in their common stock prospectus, $125 \mathrm{MW}$ out of $420 \mathrm{MW}$ are direct purchases of equipment by utilities, while the remainder is structured in the private power/project finance arrangement that has been analyzed here (Kenetech, 1993).

It may appear that utility financing would be a substantially cheaper alternative for wind power development than the private power/project financing method. The cost of capital for investor-owned utilities is certainly less than the estimates developed for wind turbine projects in Section 3. Utility financing is probably equivalent to the financing costs for conventional fossil powerplants (Kahn et al, 1992). ${ }^{12}$ Given the financing cost differential, why then would a utility prefer to obtain wind turbine output through the project finance channel rather than through direct ownership and self-financing? The answer must lie in the different incidence of risk. Under utility ownership the risk of failure or under-performance lies with the utility. In an arms-length power purchase agreement, the performance risk lies with the developer. It is beyond the scope of this analysis to assess when the balance between cost and risk would push utilities from pursuing the project finance approach to wind power development to the direct ownership approach.

An intermediate solution to the utility for assuming performance risk under a direct ownership scenario would be to arrange for production guarantees from the manufacturer. These guarantees would probably have to be tied to a maintenance contract to make them feasible. It is only reasonable to believe that a manufacturer offering such an option would have to price the risk that it entails.

It is also worth asking whether utility financing for wind turbine powerplants is really cheaper than project financing. The apparent cost advantage in no way eliminates the risks that are apparent in project financing. The economically interesting question is whether it diversifies them away, or simply conceals them. The argument for a true risk reduction by utility investment would require that there be some kind of diversification available within a utility management framework that would be unavailable to investors in the capital markets. This would be some kind of economy of scope internal to utility operations that cannot be written into a power purchase agreement. It is difficult, on first impressions, to discover what such an economy might be. If, in fact, there is no purely internal diversification benefit of utility ownership, then the apparent cost advantage of this vehicle is not really an economy. As

We neglect discussion of government owned utilities whose financing costs are substantially below those of investor-owned utilities. The two main reasons for the difference are that government owned utilities do not use expensive equity capital, and their debt costs are cheaper because their bonds are tax exempt to the purchaser. 
indicated above, there is certainly a risk transfer from private producers to the utility under the utility ownership option. There is evidence that the stock market does price this kind of risk transfer (EIA, 1994; Kahn, Stoft and Belden, 1994). Therefore, it would seem that whatever the apparent financing cost advantage of utility ownership, it may not represent a genuine cost savings. 


\section{References}

Barrett, W., A. Henson, and R. Korb., "The Effect of Three Mile Island on Utility Bond Risk Premia: A Note," Journal of Finance, v.41, no. 1 (1986) 255-261.

Benninga, S. Numerical Techniques in Finance. MTT Press, 1990.

Bergman, Y. and J. Callen, "Opportunistic Underinvestment in Debt Renegotiation and Capital Structure," Journal of Financial Economics, v.29 (1991) 137-171.

Bispham, T., "The Performance of the Public Debt Market, Proceedings of the Ninth Annual Cogeneration and Independent Power Market Conference, New Orleans, March 10, 1994.

Bodington, J., "Changing Ownership," Independent Energy, v.24, no.4 (1994) p.44.

Bradley, M. G. Jarrell and E. Kim, "On the Existence of an Optimal Capital Structure: Theory and Evidence," Journal of Finance, v.39 (1984) 857-878.

Brealey, R. and S. Myers, Principles of Corporate Finance, 4th Edition, McGraw-Hill Inc., 1991.

Caffyn, B., Cannon Power Corporation, personal communication, August 26, 1994.

Cagan, P. Changes in the Cyclical Behavior of Interest Rates. New York: National Bureau of Economic Research, 1966.

California Energy Company, Prospectus \$529,640,000 10\%\% Senior Discount Notes Due 2004, March 18, 1994.

Central Valley Financing Authority, \$142,700,000 Cogeneration Project Revenue Bonds (Carson Ice-Gen Project), July 15, 1993

Cohen, J., Advanced Horizontal Axis Wind Turbines in Windfarms, U.S. Department of Energy, 1993.

Cogentrix Energy Inc, Prospectus \$100,000,000 8.10\% Senior Notes Due 2004, March 4, 1994.

Cox, A., C. Blumstein, and R. Gilbert, "Wind Power in California: A Case Study of Targeted Tax Subsidies," Regulatory Choices: A Perspective on Developments in Energy Policy. ed. R. Gilbert, University of California Press, 1991.

Daily Journal of Commerce, "Financing for two wind energy projects announced, "January 12, 1994.

Energy Information Administration (EIA), Financial Impacts of Nonutility Power Purchases on InvestorOwned Electric Utilities. DOE/EIA-0580, 1994.

Fabozzi, F. and I. Pollack (eds.), Handbook of Fixed Income Securities, 2nd. ed. Dow-Jones-Irwin, 1987.

Gipe, P. "Windpower: Growth in Sight," Independent Energy, v.24, no.4 (1994) p.91-98.

Hadley, S., L. Hill and R. Perlack, Report on the Study of the Tax and Rate Treatment of Renewable Energy Projects, ORNL-6772, 1993.

Harris, M. and A. Raviv, "The Theory of Capital Structure," Journal of Finance, v.46, no.1 (1991) 297-355. 
Hoffman, S., "Financing Non-Utility Power Projects: A Survey of Current Developments," Nixon, Hargrave, Devans \& Doyle, Washington, D.C., 1993.

Ibbotson Associates Inc., Stocks, Bonds, Bills and Inflation 1989 Yearbook, Chicago, 1989.

Jaffe, D., "Cyclical Variations in the Risk Structure of Interest Rates," Journal of Monetary Economics, v. 1 (1975) 309-325.

Johnson, R., "Term Structures of Corporate Bond Yields as a Function of the Risk of Default," Journal of Finance, v.22 (1967) 313-345.

Kahn, E., "Risks in Independent Power Contracts: An Empirical Survey," The Electricity Journal, v.4, no.9 (1991) 30-45.

Kahn, E., Electric Utility Planning and Regulation. American Council for an Energy Efficient Economy, 2nd ed., 1991

Kahn, E., M. Meal, S. Doerrer and S. Morse, Analysis of Debt Leveraging in Private Power Projects, LBL32487, 1992.

Kahn, E., S. Stoft and T. Belden, The Impact of Power Purchases from Nonutilities on the Utility Cost of Capital, LBL-34741, 1994.

Kensinger, J. and J. Martin, "Project Finance: Raising Money the Old-Fashioned Way," Journal of Applied Corporate Finance, v. 1 (1988) 69-81.

Kenetech Corporation, Prospectus 6,000,000 Shares Common Stock, September 21, 1993.

Kessel, R. The Cyclical Behavior of the term Structure of Interest Rates. New York: National Bureau of Economic Research, 1965.

Kolbe, L., J. Read and G. Hall. The Cost of Capital: Estimating the Rate of Return for Public Utilities. MIT Press, 1984.

Myers, S., "Determinants of Corporate Borrowing," Journal of Financial Economics, v.5 (1977) 147-175.

Pacific Gas and Electric, Bidding Manual Pacific Gas and Electric Company Request for Bids (RFB) for Qualifying Facility Electric Generation Resources, 1993.

Project Finance Monthly, "Project Finance Market Wire," v.2, no.7 July, 1991.

Project Finance Monthly, "Project Finance Market Wire," v.3, no.8 August, 1992.

Project Finance Monthly, "Project Finance Market Wire," v.4, no.6 June, 1993a.

Project Finance Monthly, "Project Finance Market Wire," v.4, no.9 September, 1993 b.

Sithe/Independence Funding Corporation, Offering Circular \$717,241,000 Secured Notes, January 13, 1993.

Smith, C. and J. Warner, "On Financial Contracting: An Analysis of Bond Covenants," Journal of Financial Economics, v.7 (1979) 117-161.

Standard and Poor's, Creditreview, October 4, 1993. 
Standard and Poor's, "Independent Power Project Finance Rating Criteria, " Standard and Poor's Rating Criteria, October 17, 1991.

Stiglitz, J. and A. Weiss, "Credit Rationing in Markets with Incomplete Information," American Economic Review v.71 (1981) 393-410.

Wong, D., Kenetech Energy Systems, personal communication, August 15, 1994. 